\title{
Kelekatan Anak dengan Pengasuh Tempat Penitipan Anak
}

\author{
Heni Puspita \\ Program Studi Pendidikan Guru Pendidikan Anak Usia Dini Fakultas Keguruan Ilmu Pendidikan \\ Universitas Muhammadiyah Jember \\ Email: inehbeneh@gmail.com
}

Received March 2019, Accepted April 2019, Published April 2019

\begin{abstract}
This article aims to describe the relationship between a child who is cared for in a Child Care Center and a caregiver. This study used a qualitative approach with phenomenological research methods with the subjects of the study as many as 2 caregivers in the Yasmin Jember Day Care and 6 children who were cared for with criteria for pure day care for children and school landfill children. Child Care Center is a form of Early Childhood Education institution that functions to be a substitute carer for families with learning programs that place more emphasis on children's life skills according to the age stage. As a family substitute institution in parenting, it is common practice to form a pattern of attachment to the relationship between a child and a caregiver. Caregivers act as a substitute for parents having duties and functions to stimulate aspects of child development. In a relationship like this there is a form of acceptance or rejection that affects the closeness of the child to the caregiver.
\end{abstract}

Keywords: Pure Day Care for Children, School Landfill Children, Attachments, Caregivers

\begin{abstract}
Abstrak: Artikel ini bertujuan untuk mendeskripsikan hubungan antara anak yang diasuh di Tempat Penitipan Anak dengan pengasuh. Penelitian ini menggunakan pendekatan kualitatif dengan metode penelitian fenomenologi dengan subyek penelitian sebanyak 2 orang pengasuh di TPA Yasmin Jember dan 6 orang anak yang diasuh dengan kriteria anak TPA murni dan anak TPA sekolah. Tempat Penitipan Anak merupakan suatu bentuk lembaga Pendidikan Anak Usia Dini yang berfungsi untuk menjadi pengasuh pengganti keluarga dengan program pembelajaran yang lebih menekankan pada kecakapan hidup anak sesuai tahap usia. Sebagai lembaga pengganti keluarga dalam pengasuhan maka merupakan suatu hal yang lazim bila terbentuk pola kelekatan pada hubungan antara anak dengan pengasuh. Pengasuh bertindak sebagai pengganti orang tua memiliki tugas dan fungsi untuk menstimulasi aspek perkembangan anak. Dalam hubungan seperti ini memunculkan bentuk penerimaan atau penolakan yang mempengaruhi kedekatan anak dengan pengasuh.
\end{abstract}

Kata Kunci: Anak TPA murni, Anak TPA Sekolah, kelekatan, pengasuh

\section{PENDAHULUAN}

Pendidikan Anak Usia Dini merupakan suatu upaya pembinaan yang ditujukan bagi anak sejak lahir sampai dengan usia enam tahun yang dilakukan melalui pemberian rangsangan pendidikan untuk membantu pertumbuhan dan perkembangan jasmani dan rohani agar anak memiliki kesiapan dalam memasuki pendidikan lebih lanjut, yang diselenggarakan pada jalur formal, nonformal dan informal berdasarkan Peraturan Pemerintah No. 17 Tahun 2010. Beberapa layanan yang ada di Pendidikan Anak Usia Dini yaitu Taman Penitipan Anak, Kelompok Bermain dan Taman Kanak-Kanak. Layanan Pendidikan Anak Usia Dini pada Taman Pendidikan Anak, adapun fungsi Taman Pendidikan Anak seperti yang ditegaskan oleh
DEPSOS (2002) adalah sebagai fungsi orang tua sementara waktu (kehadiran TPA adalah untuk menjawab ketidakmampuan keluarga karena kesibukannya dalam menjalankan beberapa fungsi yang seharusnya dilakukan. Fungsi tersebut antara lain sosialisasi, pendidikan prasekolah pembelajaran prasekolah, asuhan, perawatan dan pemeliharaan sosial anak), sebagai informasi, komunikasi dan konsultasi di bidang kesejahteraan anak usia prasekolah (dalam hal ini kehadiran TPA adalah sebagai sumber informasi, komunikasi dan konsultasi tentang anak usia prasekolah beserta keluarganya kepada mereka yang membutuhkan, rujukan yaitu TPA dapat digunakan sebagai penerima rujukan dari lembaga lain, pendidikan dan penelitian yaitu TPA dapat digunakan sebagai 
tempat pendidikandan penelitian. Berdasarkan uraian diatas dapat dikatakan bahwa fungsi Taman Pentipan Anak adalah sebagai pengganti keluarga untuk jangka waktu tertentu selama oorang tuanya berhalangan atau tidak memiliki waktu yang cukup dalam mengasuh anaknya karena bekerja atau sebab lain.

Di indonesia sesuai data laporan Badan Pusat Statistik (2018-2019) Taman Penitipan Anak sampai dengan saat ini yang terdata dalam aplikasi online Managemen PAUD DIKMAS adalah sebanyak 3.024 lembaga seluruh Indonesia, di Propinsi JawaTimur sejumlah 433 lembaga, sedangkan di Kabupaten Jember sejumlah 20 lembaga. Taman Penitipan Anak telah dikembangkan oleh Departemen Sosial sejak tahun 1963 sebagai upaya untuk memenuhi kebutuhan pengasuhan, pembinaan, bimbingan, social anak balita selama anak tidak bersama orang tua. Sejak dibentuknya Direktorat Pendidikan Anak Dini Usia (Dit. PADU) tahun 2000 maka pembinaan untuk pendidikan menjadi tanggung jawab Departemen Pendidikan dan Kebudayaan. Kebijakan Direktorat PAUD untuk seluruh bentuk layanan PAUD termasuk TPA adalah layanan yang Holistik dan Integratif.

Taman Penitipan Anak merupakan program kesejahteraan anak yang dapat menyelenggarakan layanan PAUD secara terintegritas dengan perawatan dan pengasuhan anak sejak usia 3 bulan sampai dengan 6 tahun dalam UU No. 20 tahun 2003 pasal 28. Kebijakan Dit. PAUD untuk seluruh bentuk layanan PAUD termasuk TPA adalah memberikan layanan yang holistic dan integratif. Holistic berarti seluruh seluruh kebutuhan peserta didik untuk tumbuh dan berkembang (kesehatan, gizi, pendidikan, pengasuhan dan perlindungan), dilayani dalam lembaga TPA integratif berarti semua lembaga TPA melakukan kerjasama dengan lembaga mitra serta berkoordinasi dengan instansi- instansi terkait. Taman Penitipan Anak ada beberapa jenis layanan yang ada yaitu TPA murni, TPA dengan satu atap dengan PAUD lain. TPA murni yang dimaksud dalam hal ini yaitu dimana lembaga TPA murni yang berdiri sendiri atau lembaga Pendidikan Anak Usia Dini yang hanya membuka layanan TPA saja. TPA satu atap dengan PAUD lain yang dimaksud yaitu Taman Penitipan Anak dimana dalam satu atap dengan KB dan TK yang dimana ada anak TPA yang paginya bisa sekolah di situ juga.

Taman Penitipan Anak merupakan sebuah upaya terorganisir merawat dan mengasuh anak saat asuhan orang tua tidak dapat dilaksanakan secara lengkap. Bagi dual earner family, TPA idealnya bukanlah pengganti pengasuhan orang tua namun merupakan pelengkap pengasuhan orang tua (Patmonodewo 2003). Sebagai pelengkap ataupun mitra orang tua dalam mengasuh anak, keberadaan TPA saat ini sangat dibutuhkan terutama TPA dengan kualitas terbaik. Kualitas layanan TPA salah satunya dapat dilihat dari peran pengasuh (caregiver) dalam menstimulus perkembangan anak. Sama halnya dengan hubungan orang tua-anak, salah satu komponen penting dalam hubungan pengasuh-anak di TPA adalah kelekatan. Proses pembentukan kelekatan harus didasarkan pada keyakinan anak terhadap penerimaan lingkungan akan mengembangkan kelekatan yang aman dengan figur lekatnya (secure attachment) dan mengembangkan rasa percaya pada orangtua dan lingkungan (Eka Ervika, 2005: 3). Hal ini akan membawa pengaruh positif dalam proses perkembangannya, anak yang memiliki kelekatan aman akan menunjukkan kompetensi sosial yang baik pada masa kanakkanak serta lebih populer di kalangan teman sebayanya di prasekolah. Anak-anak ini juga lebih mampu membina hubungan persahabatan yang intens, interaksi yang harmonis, lebih responsif, dan tidak mendominasi 
Peran pendidik selaku pengganti orang tua dirumah dikarenakan banyak orang tua yang bekerja sehigga membantu para orang tua dalam menjalankan beberapa fungsi yang harus dilakukan, ketidak percayaan orang tua terhadap pengasuhan asisten rumah tangga dirumah dikarenakan banyaknya kasus yang terjadi di lingkungan masyarakat, sehingga tidak percayanya orang tua terhadap asisten rumah tangga sehingga orang tua lebih tenang ketika dimasukkan didalam Taman Penitipan Anak, karena di TPA anak tidak hanya sekedar dititipkan tetapi juga ada pembelajaran didalamnya guna mengembangkan aspek pada anak usia dini. Peningkatan ibu bekerja diikuti dengan meningkatnya angka anak yang dititipkan, pengasuh di TPA mempunyai peranan penting dalam proses tumbuh kembang anak terutama perkembangan bahasa (PERMENDIKBUD 2015). Perlu pemahaman hakikat anak yang berkaitan dengan pendidikan anak usia dini, yaitu kita perlu mengetahui cara mendidik anak usia dini. Secara istilah, mendidik anak usia dini sering diartikan mengasuh, membimbing serta mengembangkan potensi (kemampuan). Pengertian ini mempunyai makna bahwa seorang pendidik akan berusaha memberikan asuhan, bimbingan dan arahan dalam upaya mengembangkan potensi anak baik berupa kemampuan fisik, mental dan sosial anak.

Menurtu Kihajar Dewantara mendidik dalam arti yang sesungguhnya adalah proses humanisasi, yakni pengangkatan manusia ke taraf insani. Dalam kegiatan mendidik sering dihubungkan dengan kegiatan tiga A, yakni "Asuh", "Asah" dan "Asih". Pengertian mendidik sering kali diputarkan maknanya dengan istilah mengajar dan melatih. Mengajar atau memberikan ajaran sebenarnya merupakan bagian dari proses mendidik itu sendiri, terutama pada kegiatan "asah" atau mengasah. Asuh adalah usaha pendidik mengantarkan dan mengarahkan kehendak (keinginan) anak ke arah yang baik (benar) misalnya anak ingin bermain lumpur, maka pendidik akan berusaha mengikuti kegiatan anak tersebut dan mengarahkannya pada hal yang baik (seperti bermain lumpur dengan membentuk sesuatu). Arahan pendidik seperti itu sebenarnya sekaligus melaksanakan kegiatan "Asah" atau mengasah (menajamkan) pikiran (otak) anak melalui berbagai bentuk kegiatan yang disukainya. Segala bentuk tindakan pendidik dalam kegiatan "Asuh" dan "Asah" harus dilandasi oleh sikap "Asih" atau welas asih (kasih sayang). Dengan kata lain, setiap perbuatan pendidikan harus didasarkan pada kasih sayang dan kecintaan yang tulus pada anak usia dini. Ketika seorang pendidik/pengasuh bisa melakukan kegiatan A dengan baik maka kelekatan antara anak dan pendidik/pengasuh akan terjalin, walaupun anak tersebut bukan anak didiknya.

Kelekatan mengacu pada ikatan spesial atau khusus yang didirikan oleh kualitas hubungan yang unik antara ibu dengan anaknya atau antara pengasuh dengan dengan anaknya dan seblaiknya melalui proses perlahan (Hastuti, 2015). Kelekatan merupakan suatu ikatan emosional yang kuat yang dikembangkan anak melalui interaksinya dengan orang yang mempunyai arti khusus dalam kehidupannya, biasanya orang tua (Mc Cartney dan Dearing, 2002). Pada hal ini kelekatan yang dilihat adalah kelekatan aman anak dengan pengasuhnya di TPA. Kelekatan merupakan tingkah laku yang khusus pada manusia, yaitu kecenderungan dan keinginan seseorang untuk mencari kedekatan dengan orang lain dan mencari kepuasan dalam hubungan dengan orang tersebut.

Kondisi kelekatan anak dengan pengasuh bisa dikatakan lekat pada orang lain jika mempunyai kelekatan fisik dengan seseorang, menjadi cemas ketika berpisah dengan figur lekat, menjadi gembira dan lega ketika figur lekatnya kembali, dan orientasinya tetap pada figur lekat walaupun tidak melakukan interaksi. Sebaliknya pengasuh yang tidak menyenangkan akan membuat anak 
tidak percaya dan mengembangkan kelekatan yang tidak aman (insecure attachment). Kelekatan yang tidak aman dapat membuat anak mengalami berbagai permasalahan yang disebut dengan gangguan kelekatan (attachment disorder). Apabila anak terjadi gangguan kelekatan, hal ini akan membuat anak mengalami masalah dalam hubungan social. Beberapa penelitian menunjukkan bahwa anak yang mengalami gangguan kelekatan memiliki orang tua yang juga mengalami masalah yang sama dimasa kecilnya (Sroufe dalam Cicchetty dan Linch, 1995). Anak memperhatikan gerakan, mendengarkan suara dan sebisa mungkin berusaha mencari perhatian figur lekatnya. Anak-anak memperhatikan kebiasaan yang dilakukan oleh figure lekatnya tersebut, hafal dengan barang-barang di setiap hari dipakai atau dipegang oleh figure lekatnya itu, ketika dimintai pertolongan seperti untuk mengambilkan handpone atau tas yang dimiliki figure lekatnya tidak usah dengan dua kali dimintai tolong, dengan satu kali perintah maka anak itu akan tahu dimana barang tersebut biasa diletakkan.

Pengasuh sebagai pengganti ibu dalam merawat dan mengasuh anak memiliki pengaruh yang berdampak pada perkembangan anak. Anak-anak yang diasuh oleh figur lekat pengganti yang memiliki pendidikan rendah memungkinkan resiko menurunnya perkembangan anak. Hal ini sesuai dengan dugaan penelitian Latifah et al. (2016) yang menyebutkan bahwa pengalihan pengasuhan anak kepada nenek yang memiliki pendidikan rendah berpengaruh terhadap perkembangan kognitif anak. Pada keluarga perkotaan pengalihan pengasuhan kepada nenek digantikan oleh pengasuh di TPA. Kualitas pengasuh TPA tentu memiliki pengaruh yang cukup besar terhadap perkembangan anak asuhnya. Semakin tinggi kualitas perawatan anak maka semakin tinggi perkembangan anak terutama perkembangan kognitif, namun semakin rendah kualitas perawatan anak maka semakin rendah pula perkembangan anak (Jay Belsky 1991 dalam Child and Youth Studies Group at the Open University 2007).

Banyak karakteristik anak yang ada di TPA karena di TPA beda dengan layanan PAUD seperti KB dan TK yang disesuaikan dengan umur, Ketika ada seorang pengasuh yang meminta tolong kepada salah satu anak di TPA murni untuk mengambilkan tepak pensil diatas meja yang dipunya oleh salah satu guru, anak tersebut langsung mengambilkan dengan benar kotak pencil milik guru tersebut, padahal diatas meja terdapat beberapa tepak pencil milik guru yang lain, akan tetapi anak tersebut dapat mengambilkan tepak milik guru tersebut dengan benar, dari kejadian tersebut sudah terlihat yang namanya kelekatan, terlihat dari anak tersebut hafal barang yang dimiliki oleh guru tersebut, di TPA ini semua umur ada, jadi banyak sekali karakteristik dan tipe-tipe anak yang ada, ada anak yang merasa bunda/pengasuhnya hanya miliknya dan temannya tidak boleh memilikinya, ada anak yang biasa saja sehingga anak ini ketika teman lain mendekati gurunya dia akan biasa saja, ada yang biasa saja tetapi mengamati.

\section{METODE}

Metode penelitian yang digunakan dalam penulisan artikel ini menggunakan metode penelitian Deskriptif Kualitatif. Menurut Sugiyono (2017) menyatakan bahwa metode penelitian yang berlandaskan pada filsafat postpositivisme, digunakan untuk meneliti pada kondisi obyek yang alamiah, (sebagai lawannya adalah eksperimen) dimana peneliti adalah sebagai instrumen kunci, pengambilan sampel sumber data dilakukan secara purposive dan snowbaal, teknik pengumpulan dengan trianggulasi (gabungan), analisis data bersifat induktif/kualitatif dan hasil penelitian kualitatif lebih menekankan makna dari pada generalisasi. 
Teknik pengumpulan data peneliti melakukan wawancara terhadap guru dan observasi terhadap anak, dalam hal ini anak terdiri atas anak TPA murni dengan TPA sekolah dengan menggunakan teknik analisis data yaitu teknik validasi data.

Kegiatan penelitian ini dilakukan di Sekolah Laboratorium PAUD Yasmin Fakultas Keguruan Ilmu Pendidikan Universitas Muhammadiyah Jember dikarenakan ini merupakan laboratorium Program Studi Pendidikan Guru Pendidikan Anak Usia Dini, dimana lokasi sekolah laboratorium ini satu lingkungan dengan Program Studi Pendidikan Guru Pendidikan Anak Usia Dini. Subjek yang diteliti merupakan anak yang dititipkan Taman Penitipan Anak (TPA) yang ada di Sekolah Laboratorium PAUD Yasmin tersebut, subjeknya sebanyak empat anak yang terdiri dari dua laki-laki dan dua perempuan. Penelitian ini dilakukan antara bulan Januari hingga maret 2019.

\section{HASIL DAN PEMBAHASAN}

Sebelum melakukan penelitian, langkah awal peneliti melakukan observasi tempat di beberapa Taman Penitipan Anak yang berada di Kabupaten Jember dan peneliti memutuskan untuk melakukan observasi ini di Sekolah Laboratorium PAUD Yasmin Fakultas Keguruan Ilmu Pendidikan Universitas Muhammadiyah Jember, karena Sekolah Laboratorium PAUD Yasmin ini merupakan Laboratorium Program Studi Pendidikan Guru Pendidik Anak usia Dini yang bertempat satu kawasan di kampus Universitas Muhammadiyah Jember. Taman Penitipan Anak di Sekolah Laboratorium PAUD Yasmin ini satu atap dengan layanan Pendidikan Anak Usia Dini yang lain seperti Kelompok Bermain dan Taman Kanak-Kanak.

$$
\text { Langkah selanjutnya peneliti }
$$
menentukan obsek yang akan diteliti yaitu dengan meneliti empat orang anak yang terdiri dari dua anak laki-laki dan dua anak perempuan. Nama anak tersebut Fatir, Rasya, Alya dan Nafisa, kedatangan anak-anak TPA tidak seperti Kelompok Bermain dan Taman Kanak-Kanak yang jam 07.30 sudah masuk, akan tetapi TPA tidak ada ketentuan jam masuknya, akan tetapi ke 4 anak tersebut masuk sesuai jam masuk di PAUD Yasmin, kedatangan anak disambut dengan pangasuh TPA didepan kelas mereka dibiasakan untuk berjalan sendiri ketika masuk gerbang sampai keruangan TPA, dengan berinteraksi mengucap salam, memeluk dan pengasuh menanyakan kabar ke anak dan anak menjawabnya dengan penuh senyuman. Ada salah satu anak yang datang akan tetapi menanykan salah satu pengasuh yang tidak terlihat didepan untuk menunggu kedatangan tidak ada didepan akhirnya anak tersebut nmerasa cemas dan burujung menangis, setelah tahu keberadaan pengasuh tersebut dibelakang rasa cemaspun hilang. Bel pun berbunyi sehingga anak-anak dan pengasuh berkumpul di halaman kelas untuk melakukan kegiatan circletime, selesai melakukan circletime anak- anak melakukan kegiatan motorik kasar di depan halaman kelas bersama-sama.

Selesai kegiatan di halaman kelas anak-anak masuk bersama pengasuhnya untuk melakukan kegiatan selanjutnya seperti Toilet Training, sholat dhuha bersama dan melakukan kegiatan pembelajaran lainnya yang dilakukan setiap hari bersama anak dan pengasuh. Pembelajaran inti selesai dilakukan, waktunya untuk melakukan beres-beres yang dilakukan oleh pengasuh dan anak, anak -anak membantu pengasuh untuk membereskan mainan yang telah dimainkan bersama, ketika pengasuh akan menaikkan mainan ke atas loker tiba-tiba tempat mainan yang dibawa pengasuh jatuh, dengan spontan anak-anak membantu tanpa dimintai tolong. Waktu istirahat tiba anak-anak makan bekal yang dibawakan oleh orangtuanya, anak yang TPA sekolah pun juga datang dan mengganti pakaian sekolahnya denganpakaian santai, 
pada saat istirahat terlihat ada dua orang anak TPA murni yang memberikan sebagian makanan tersebut untuk salah satu pengasuh yang ada di TPA, kemudian disusul oleh beberapa anak juga membagi makanan untuk salah satu pengasuh yang lain, semua peralatan seperti baju, susu dan sabun mereka keluarkan dari tasnya untuk diberikan kepada pengasuh. Pada saat pengasuh membawa peralatan tersebut untuk diletakkan diloker ada beberapa anak yang membantu membawakan peralatan tersebut, ada yang membawakan baju untuk diletakkan ketempat baju, ada yang membawakan susu untuk diletakkan ditempat pembuatan susu.

Waktu menunjukkan makan siang, anak-anak persiapan makan siang dan tidur siang, semua anak TPA murni dan TPA sekolah berkumpul duduk untuk menunggu panggilan pengasuh yang sudah menyiapkan makan siang, salah satu dari pengasuh menata kasur, bantal dan guling, ada beberapa anak TPA murni yang membantu pengasuh untuk menata kasur, bantal dan guling. Waktu makan siang pun sudah siap dan pengasuh yang bertugas menyiapkan makan siang sudah memanggil anak-anak ke dapur untuk mengambil kursi untuk persiapan makan, makan siang pun sedang berlangsung dan beberapa menit kemudian sudah selesai semua, ada beberapa anak yang masih dibelakang membantu pengasuh untuk membereskan kursi teman-temannya yang lupa untuk dikembalikan lagi ketempat kursinya semula. Jam tidur siangpun tiba, anak anak menempati tempat tidur yang sudah disediakan oleh pengasuhnya untuk tidur siang dari jam 12.00 sampai jam 14.30, sampai waktu mandi tiba anak-anak persiapan untuk mandi. Pukul 16.00 pun tiba, anak-anak satu persatu dijemput oleh orang tuanya, peluk dan cium selalu mereka lakukan ketika pulang, kata-kata motivasi yang dilakukan oleh pengasuh selalu diucap untuk memotivasi mereka.

\section{SIMPULAN}

Penelitian ini dilakukan di Sekolah Laboratorium PAUD Yasmin Fakultas Keguruan Ilmu Pendidikan Universitas Muhammadiyah Jember. Observasi dilakukan dengan empat anak yang terdiri dari dua lakilaki dan dua perempuan, dimana anak tersebut sudah 2-3 tahun berada di Taman Penitipan Anak PAUD Yasmin. Hasil dari penelitian kelekatan itu tumbuh ketika anak sudah merasa nyaman di TPA itu dan keberadaan anak itu memang sudah lama dari 2-3 tahun. Bentuk kelekatan yang terlihat ketika salah satu anak datang tidak di jemput pengasuh yang di sukai anak tersebut merasa gelisah, ketika pengasuh kesulitan membawa sesuatu anak-anak membantu seperti mereka sudah tauapa yang ahrus dilakukan untuk menolong orang yang dia sayang.

\section{Saran}

Berdasarkan hasil penelitian yang diuraikan diatas maka peneliti menyarankan agar dipertahankan atau dikembangkan lagi kegiatan-kegiatan pembelajaran yang mengikut sertakan pengasuh dengana anak sehingga kelekatan aman terhadap pengasuh dan anak akan terasa.

\section{DAFTAR PUSTAKA}

Dessy, H. (2010). Taman Penitipan Anak Sebagai Rumah (Home) Kedua bagi Anak Usia Prasekolah. Skripsi. Diunduh pada Tanggal 16 Februari 2019 pukul 23.23 WIB.

Evrika, E. (2005). Kelekatan (Attachment) Pada Anak. Skripsi. Content://com.sec.android.app.sbrowser .scraplist/0521001038.html. Diunduh pada tanggal 16 februari 2019.

Nurhidayah, S. (2011). Kelekatan (Attachment) dan Pembentukan Karakter. Jurnal Turats. Volume 07, No:2 
Jurnal PG-PAUD Trunojoyo : Jurnal Pendidikan dan Pembelajaran Anak Usia Dini, Volume 6, Nomor 1, April 2019, hal $49-55$

Sugiyono. (2017). Metode Penelitian

Pendidikan. Bandung: Alfabeta 